\title{
Exploring Informality In A Global South City: Issues Of Power And Urban Development In Kuala Lumpur
}

\author{
Rosilawati Zainol ${ }^{1}$, Luiza FL Sarayed-Din ${ }^{2}$, and Faizah Ahmad ${ }^{3}$ \\ 1, 2 Centre for Sustainable Urban Planning and Real Estate (SUPRE), Faculty of Built Environment, \\ University of Malaya, 50603 Kuala Lumpur, Malaysia. \\ "rosilawatizai@um.edu.my
}

Received: 11 November 2016 Final Version Received: 1 June 2017

Framed by global south urban studies' discussions about the issues of power in the production of informality, this paper critically assesses the urban development history of a traditionally inhabited area in Kuala Lumpur, Malaysia. Based on the analysis of official documents and 18 months of observation and application of semi-structured interviews with key stakeholders, this paper first presents the urban development history of this area, and then discusses it in light of two emergent themes associated with issues of power in informality, namely state power and market forces. Casting a critical eye towards the idea of informality as something that should be 'fixed' by urban development practices, this work discusses the sharp influence of state power and market forces in the production of informality in Kuala Lumpur and, consequently, in other global south cities.

Keywords: Informality, Global South, Power, Development, Kuala Lumpur

\footnotetext{
${ }^{1} \mathrm{PhD}$ candidate at the Faculty of Built Environment, University of MalayaEmail: luiza.sarayed@gmail.com

${ }^{2} \mathrm{PhD}$ candidate at the Faculty of Built Environment, University of MalayaEmail: luiza.sarayed@gmail.com

${ }^{3}$ Registered Town Planner, Malaysian Institute of Planners. Email: faizah2108@yahoo.com.au
} 


\section{INTRODUCTION}

The beginning of the $21^{\text {st }}$ century marked a major shift in the urbanization of the world. In 2006, the World Planners Congress and the United Nations Habitat World Urban Forum officially announced that, for the first time in history, the majority of human population lives in cities, with the global south being the new epicenter of urbanism. These massive economic and demographic shifts have revealed the inadequacy of the current planning practices in efficiently addressing global south cities' core issues. Prioritizing ideas that come from the Anglophone cities forged by the Industrial Revolution, these existing urban practices have the 'tendency to overlook the rapidly growing cities where traditional authority, religious identity or informality are as central to legitimate urban narratives as the vacillations in modern urban capitalism public policy' (Parnell and Oldfield, 2014: 2). At the outset, these major shifts have shown the urgency of planning practitioners to develop a different approach committed to reduce inequalities within growing cities acknowledging their histories, experiences and way of living(UN-HABITAT, 2006).

Molded by the complex mixture of colonial background, rapid urban growth and dubious modernist planning practices, the city of Kuala Lumpur, Malaysia is considered an insightful example of a global south city. Going through a sequence of urban development transformations since the 1990s, Kuala Lumpur faces big challenges that are rooted in its planning practices. More specifically, the development interventions in and around the emblematic area of Kampong Bharu located in the heart of the city highlight the urge of an urban practice compromised with different ways of looking at informality. Aiming to address such challenge, this study investigates this historical inhabited urban area's development history framed by one of the critical elements of informality indicated by the southern urbanism: power (Yiftachel, 2009; Roy, 2005; Roy, 2009; Watson, 2006).

Given the nature of this challenge, which is intertwined with people's relations, issues of power and impact of history, this study follows a social constructivist approach and qualitative methodology. The data collection, on the other hand, ranged from substantial literature review and desk study gathering historical, governmental, media and technical data to 18 months of observation and application of semistructured interviews with key stakeholders. The population profile composed by 10 key stakeholders was identified through a combination of secondary data review, as well as primary source referral, following both an organizational and area connection criteria in order to reveal context-rich information. Whilst the stakeholders chosen under the criteria of connection with the area represent the region's gatekeepers - namely residents and local organizations - the official sources of the development intervention are represented by the government, development bodies and specialists.

Framed by the above-mentioned methodological choices, this paper firstly presents the urban development history of Kampong Bharu, focusing on the current Kampong Bharu Master Plan. It then discusses it in light of two emergent themes associated with issues of power in informality in global south cities, namely state power and market forces. Exploring the case of this historical inhabited urban area under the pressure of urban development anddiscussing the sharp influence of both emergent themes in the production of informality in Kuala Lumpur, this study adds on the insipid repertoire of experiences associated with informality in global south cities. Rather than be considered as representative of all global south cities in the world, Kuala Lumpur has been chosen for what can be learned from this city, which is shaped by its recent colonial past and development practices.

For the purpose of this study, the term 'global south' refers to a broaden and nonhierarchical frame of view that acknowledges the common 'colonial past and more recent 
shared development history'(Miraftab and Kudva, 2014: 4) of certain cities.

\section{INFORMALITY IN GLOBAL SOUTH CITIES}

Focusing on experiences of cities everywhere, but in particular those of the global south, a group of authors have broadened the understanding of informality. Casting a critical eye towards the idea of informality as something that should be 'fixed' by urban development practices, authors such as Roy (2009); Simone (2004); Yiftachel (2009); Watson (2009) see it as a structural planning feature historically conducted by state power and intertwined by both market forces and survival efforts of the marginalized. They argue that rather than solving the informality issue, the urban development planning are usually both driven by as well as reinforcing informal practices. Watson (2009), for instance, clarifies that it is in the interface of modernization state efforts, urban administration or political control, market regulation and their target population that informality takes place. In Roy (2009: 82)'s words, 'the splintering of urbanism does not take place at the fissure between formality and informality but rather, in fractal fashion, within the informalized production of space'.

Discussing in depth the official notion and narrative of development within Africa, AbdouMaliq Simone (2004) critiques what is conventionally known as legality/illegality, formal/informal,etc., documenting and analyzing the emergent forms of social collaboration and their importance in the remaking of a broad range of African cities. As another example, drawing on the Indian context, Roy (2009) discusses the question 'why some forms of informality are criminalized and thus rendered illegal while others enjoy state sanction or are even practices of the state'(83). Also touching the intricate issue of power as a determinant in what is regarded or not as informal, Oren Yiftachel (2009) examines the case of marginalized communities of urban Israel/Palestine and expands the understanding of contemporary urban colonial relations going beyond the European colonialism or subsequent post colonialism. For him, these new types of colonial relations are materialized in the city's " "gray spaces", positioned between the "whiteness" of legality/approval/safety, and the "blackness"

of eviction/destruction/death'(Yiftachel, 2009: 88).

All in all, the common ground of understanding of the studies committed to a new way of looking at informality in the global south cities is thebroadening of the understanding of informality as an idiom of urbanization, which is expressed in both the built environment and the decision-making processes of all kinds that disregard the formal rules and regulations. Generally considering history, people's relations and the issues of power as determinants for a broadened understanding of informality: they invite planners to discuss such critical elements as responsible for the very production of the global south cities' crisis.

Conscious of the complexity of each of those critical elements, this paper focuses on one of them: the issues of power.

\subsection{POWER AS A CRITICAL ELEMENT OF INFORMALITY}

Addressed by the above-quoted authors, the issues of power within urban planning are usually examined under two main topics: the ideological and the state power. For instance, Yiftachel (2009); Roy (2005); Roy (2009); Watson (2006) make use of upgrading and urban development experiences to exemplify the political and market forces within planning territorial practices, and homogenization of planning interventions across the globe. Casting a critical eye toward the hidden forces within planning, they have questioned both the generalized assumptions regarding 'good planning' and the legal apparatus responsible 
for legitimization, eviction and oblivion of urban areas and population.

The ideological issues of power are mostly related to such 'good planning' assumptions that are informed by a set of taken-for-granted universal values. As highlighted by Vanessa Watson (2006: 38), 'planning decisions of all kinds are inevitably value-laden'. Agreeing with Watson, Roy $(2005,2009$ c) emphasizes that from the mainstream planning solutions to the culture of a dominant group expressed in practices and comportment of planners, a set of dominant values and ideology can be seen. For instance, anchored in the micro-practices of everyday life, such power forces are embedded in both the legislative framework of planning (Sandercock, 2003) as well as the 'modern' planning strategies such as gated villages, competitive city strategies and public service privatization (Watson, 2006).

Furthermore, addressing intricate questions such as 'Who sets the urban upgrading agenda?' and 'Can the public interest of the city be left in the hands of private developers?'Roy (2009: 77) adds another example of ideological power within planning: the private forces. She argues that when private means emerge as an alternative for the lack of public presence, the upgrading agenda very often addresses only the space and physical amenities rather than the real population's demands. Calling it the hegemonic market rationality, Watson (2006) uses the promotion of competitive cities as an example of how the real state and private interest quite often drive the planning spatial choices.For instance, she explains, in order to attract 'global investment, tourists and a residential elite through upmarket property developments, waterfronts, convention centres and the commodification of culture and heritage ... New spatial policies are thus reinforcing social divides'(Watson, 2006: 37).

Also concerned about issues of power associated with legal apparatus responsible for legitimization, eviction and oblivion of urban areas and population, those authors have explored the complex topic of state power within planning. Talking about the Indian planning system, Roy (2009: 81) sharply declares that 'the state, as the sovereign keeper of the law, is able to place itself outside the law in order to practice development'. Exploring the urban development dynamics of Indian cities, she defends that the state power plays a pivotal role in defining which forms of living and being will thrive and which will disappear in the urban scenario. Broadening this perspective to other global south cities, Watson (2006) affirms that such state-power definitions usually trigger world-view clashes between the everyday survival experiences of city dwellers and the state assumptions regarding what is a 'proper urban environments - free of informal settlements and street-traders, and with a citizenry attuned to the marketization of public services'(38).

Using the colors white, black and grey as a metaphor for territorial state and ideological power, the Israeli planner Oren Yiftachel (2009) grounds this theoretical discussion in a didactic manner. Drawing on Israeli/Palestinian cities'struggles in handling the urban policies impacts into fostering or maintaining a deeply unequal urban society.Yiftachel (2009: 90) sees those experiences as 'hyper-examples of structural relations', which may be found in many other cities around the changing globe. The tools and discourses of planning, he argues, are used by the state as a way of legitimizing and recognizing - whiten - and criminalizing and delegitimizing - blacken entire urban areas and populations.

Given that, Yiftachel (2009) offers a practical tool for a critical analyses of planning in global south cities: the identification of white spaces as the accepted, black as unaccepted/ criminalized, and grey as purposely forgotten. It is important to notice that the usage of such divisions brings out the power relations and set of values that informs such definitions in cities. The highlighted issue posted by the author is the very existence of planning as a tool used by state and ideological power responsible for both the existence and 
criminalization of informal or 'undesirable' city spaces.For him,

'Urban plans design the city's "white" spaces, which usually create a little or no opening for inclusion/recognition of most informal localities and population, while their discourse continuously condemns them as chaotic danger to the city. Under these circumstances we must of course consider selective nonplanning as part of planning, and as a form of active or negligent exclusion. In these pervasive settings planning is far from a profession promoting just and sustainable urbanism; it is rather a system managing profound societal inequalities - a system of "creeping apartheid"”. (Yiftachel, 2009: 93)

\section{KAMPONG BHARU URBAN DEVELOPMENT}

Kuala Lumpur's traditional urban village Kampong Bharu was set up as a Malay Agricultural Settlement (MAS)in 1899, when the Malay states were under British rule. Before that time, land was plentiful and there was no need for regulatory land systems. However, with the British domination from 1874 onwards, the city received a great contingent of emigrants, particularly British and Chinese mining workers, triggering a foreign urban sprawl causing eviction of indigenous Malays in Kuala Lumpur ( $\mathrm{Ju}$ et al., 2012). In order to minimize such effect, the colonial government separated a piece of land in the north of Kuala Lumpur exclusively dedicated to Malays: the Kampong Bharu which in Bahasa Malayu means New Village.

Strongly marked by its history and continuous state-led urban interventions within and surrounding Kampong Bharu, this urban village represents a complex terrain. For instance, Kampong Bharu's almost insoluble land issue has its origin in 1900, once theMAShad been created. The allowance to live in that region was ethnically guided - only
Malays - and,in theFederation of Malaya Government Gazette of 1951, the description of what it meant by 'Malay' was registered. A Malay, the document says, is who belongs to 'any Malay race who habitually speaks the Malay language, professes the Muslim religion and practices Malay customs and a person approved by the board as Malay'(Selangor, 1951: 18).

To complicate matters further, the political governance of Kampong Bharu is still a sensitive issue. For instance, although Kuala Lumpur became a Federal Territory in 1974, Kampong Bharu was still mentioned in the 1987 Selangor State Government Land Enactment, under section 6 (Azuidah, 2011). Besides the Kuala Lumpur City Hall and Selangor state governance responsibility over Kampong Bharu, the first official MAS document assigns a management board to have full strategic and executive powers over the Kampong Bharu area. This board still exists today and, as per the Federation of Malaya Government Gazette of 1951, is still responsible to frame by-laws, authorize and register dwellers, etc. (Selangor, 1951). In addition to that, another example of governance and land issues in Kampong Bharu is that it was only in 1964 that the settlement dwellers - who used to be allowed to live on but not own the land - were granted the ownership of their land by the state of Selangor (Teng, 2014).

After independency and following the New Economic Policy (NEP) era, Kampong Bharu attracted a large contingent of Malays migrating from all over Malaysia and neighboring Malay countries, and Kuala Lumpur City Centre became the most strategic area of government investment. From that time onwards, Kampong Bharu has remained the bastion of a Malay Kuala Lumpur and has, at the same time, been under the pressure of the 'new modern Malaysia' symbolized by shopping, business skyscrapers and high-end condominiums. As King (2008)sharply accuses, after so many modernizing interventions surrounding Kampong Bharu, the 
settlement '... stands as a symbol of past oppressions, of Malay economic stagnation, of radical responses in a generally docile community and of economic opportunities lost or stolen by misguided law'(King, 2008: 38).

On top of that, Bunnell (2002) suggests that the very existence of a kampong within the heart of a would-be world-class city and nation reveals the urban limits of such authoritative urban practices. Explaining the history and investigating the values underneath the rise of such new urban Malayness discourse, in which " "modern" and "clean" city landscapes have been inherited as a barometer for the progress of Malaysia,Bunnell (2004: 302)highlights that the term 'kampong' is usually associated with urbanization failure and something undesirable.

Keeping that in mind, it is important to highlight that since the 1984 Kuala Lumpur Structure Plan (KLSP) there were different government efforts in 'solving' the Kampong Bharu issue. In the 1984 KLSP, for instance, there is a whole section dedicated to Malay Reservation and, more specifically, to Kampong Bharu. In this document, Kampong Bharu is explicitly considered the area with 'highest potential for development'due to its'close proximity to the urban opportunities of the city center'(Kuala Lumpur City Hall, 1984: 174). Stating that the major problems of Malay Reservations' low path in changing 'from the basically rural settlement and activities to the modern urban norms'stems from legal to socio-psychological constrains, the Kuala Lumpur City Hall (1984: 175) underscores that Kampong Bharu is expected to be the locus for fostering 'Bumiputera's presence in the Federal territory urban economy'.In order to achieve that, the plan suggests both the formation of a dedicated corporation to facilitate the development of all Malay Reservation areas and the support of private-led anchor projects (Kuala Lumpur City Hall, 1984).

However, it was during the 1990s that Kampong Bharu witnessed the biggest 'modernization' pressure. Embedded in the principles of Vision 2020, major developments in Kuala Lumpur City Centreinclude the demolitionof the bridge connecting Kampong Bharu and the city center, and the building of a wall contiguous to the newly constructed Ampang-Kuala Lumpur Elevated Highway (AKLEH), the first elevated highway in Malaysia, in 1996. Another example is the construction of Kampong Bharu Light Rail Tranit (LRT) station in 1999 next to this wall as seen on 2004 map analysis by Nor and Naziaty (2011). All in all, most of the urban interventions and mega projects associated with the development of Kuala Lumpur City Centre throughout the1990s had an immense impact on Kampong Bharu everyday life.

Produced as part of the Kuala Lumpur City Plan 2020 (Kuala Lumpur City Hall, 2006), Kampong Bharu received a new Development Plan in 2008. Although launched two years later, this study was considered the Volume 4 of the whole City Plan and had a strong focus on real estate development in and around Kampong Bharu. In detail, the plan presents four potential development scenarios for Kampong Bharu. Increasing the level of interventions and real estate development, the scenarios were: $1^{\text {st }}$ 'Following the trend', $2^{\text {nd }}$ 'Developing selected lands', $3{ }^{\text {rd }}$ 'Re-integrating the area to the surroundings', $4^{\text {th }}$ 'Comprehensive development'. Besides that, a detailed set of development proposals for each area of Kampong Bharu and a potential governance structure and estimated costs were presented. The suggestions stemmed from the development of Auto-City mall to the design of a backup water supply system for the region (Kuala Lumpur City Hall, 2008).

\subsection{DEVELOPMENT MASTER PLAN OF KAMPONG BHARU 2014}

In 2014, however, a further step was made towards Kampong Bharu redevelopment. Following some of the general guidelines of the 1984 and 2003 KLSP and Kampong Bharu Development Plan 2008 governance indications, the Kampong Bharu Development Corporation (PKB (Perbadanan Pembangunan Kampong Bharu, in Bahasa Melayu)was officially formed in 2011 (Parlimen Malaysia, 
2011). Based on the fourth scenario of the 2008 Kampong Bharu plan, the one contemplating major changes and intervention, the PKB launched the Comprehensive Development Master Plan of Kampong Bharu in 2014. With a strategically powerful message, the mission and vision of this master plan highlight both the Malay culture and economic boost of Kampong Bharu, as well as the importance of landowners to not be 'left behind in the future development path'(PPKB, 2014: 1.2, author's translation).

Consequently, it is important to highlight that with the creation of the Kampong Bharu Development Corporation through the Act 733 (Parlimen Malaysia, 2011), the plot ratio of Kampong Bharu area has been increased from $1: 6$ to $1: 10$, which is the highest of Kuala Lumpur - only Kuala Lumpur City Centre's area has similar plot ratio. In addition to that, the land use that was mostly for agricultural and residential purposes in 1960s (Nor \& Naziaty, 2011) has been changed for business and commerce use.

Based on Kampong Bharu development's first two objectives stated inthe Kuala Lumpur City Plan 2020 (2006), as well as the Kampong Bharu Master Plan (2014: 29), this urban intervention should enhance growth by 'encouraging innovative solutions in planning land development and redeveloping areas with catalyst activities'. Overall, within the package of innovative solutions PPKB (2014) included in the intensive mixed-use development, based on vertical growth, is increasing the density ofresidents from 18,372 to 70,000 (PPKB, 2014: 33) and attracting a variety of businesses to enhance the value and usage of the land. Further, as highlighted on thePPKB (2015) website, in order to make Kampong Bharu a profitable business area, the development focuses on strengthening trade and financial activities towards international trade and knowledge base.

From the perspectives of the new population density and business space, Kampong Bharu Master Plan expects that by 2035 more optimal business spaces (from
123,539 sq. feet to $53,336,130$ sq. feet in 2035 (PPKB, 2014: 34)) as well as 17,500 housing units of various sizes and levels of capability are going to be available for a new and diverse population of Kampong Bharu. The vertical growth is boosted by the recent increase of the Kampong Bharu plot ratio from 1:6 to $1: 10$. Whilst for the redevelopment of catalyst actions, PPKB (2014) suggests the upgrade of existing economic practices, as well as the implementation of new catalyst activities in order to attract other businesses and people for the area. In the Master Plan, six categories are identified as catalysts: the traditional food and commerce, education, travel and tourism, car, fashion, and medical (PPKB, 2014: 29). In addition to that, nine other general activities, such as the construction of hotels and serviced apartments, are indicated as catalysts to be implemented throughout the development intervention in order to attract people and investment to the area.

All in all, seen always as an issue and a place to be 'modernized', from the first attempt in 1985, followed by the comprehensive Kampong Bharu Development Plan in 2008 and currently the Kampong Bharu Master Plan launched in 2014, Kampong Bharu has always been a conflicting arena of political and economic discussion, legal lacunas, and ethnical and religious affirmation.

\section{ISSUES OF POWER IN KAMPONG BHARU URBAN DEVELOPMENT}

The aforesaid sequences of development interventions within and around Kampong Bharu have briefly explained the situation of urban pressure and decay that the area and its population have been historically facing - from as early as 1984 to 2015 - emphasizing the role of planning on the production of informality. With empirical examples stemming from the informality expressed through the attitude that regards as undesirable the planning history of a specific group to the land issues restricted by the same planning that is supposed to solve them, the critical assessment of these 
development practices highlighted the underlying assumptions of informality in Kampong Bharu development.

In addition to that, the brief theoretical framework of informality in the global south associated with the field work in Kampong Bharu has raised two emergent themes related to issues of power in informality, namely state power and market forces. Those themes, as one may notice in the following sub-sections, are consistent with experiences of other research around the world - particularly global south research - that call into question the ways informality is often used in urban planning.

\subsection{STATE POWER}

As briefly explored in this paper, in studying Indian, African and Israeli/Palestinian cities' planning systems, Roy (2009), Watson (2006) and Yiftachel (2009) have identified the pivotal role of state power in defining which forms of living and being will thrive and which will disappear in the urban scenario. In the case of Kuala Lumpur, more specifically in and surrounding the Kampong Bharu area, this study suggests that the urban reality does not differ from these other global south cities. For instance,both official and media writings, as well as interviewees' statements emphatically state that the most recent Kampong Bharu urban intervention seeks to modernize the area.

Delving deeply into the underlying meaning of modernity for these different sources, one might notice that it is usually used in opposition to slum, kampong and poor. Bringing back Bunnell (2002)'s statement about the term 'kampong' being usually associated with urbanization failure and something undesirable, the government urban interventions surrounding Kampong Bharu offer a great example of the Malaysian state power role in dictating what is considered a proper urban environment in the world-class city of Kuala Lumpur. As an example, these legitimization efforts from the state considering a certain concept of cleanliness, organization and landscape as modern - whiten in Yiftachel (2009)'s words - and criminalizing, delegitimizing - or blacken (Yiftachel, 2009) can be observed in the three following quotes from government authorities and development body representatives associated with the current Kampong Bharu Master Plan. For them, this urban intervention is supposed to reduce the gap between Kampong Bharu's current situation and the surrounding modernbuilt environment.

Respondent a: ${ }^{6} \ldots$ the issue is the disparity between this area, the so-called Malay area, as compared to the whole Golden Triangle area like Bukit Bintang and Jalan Ampang. The issue is that it (Kampong Bharu) is a really impoverished area. So what we plan to do, after so many ideas mooted from the former prime ministers until the present one - since 1978 if you can remember very well - is to make sure to bridge the gap between the well-developed area and this what is called slum in a way (Kampong Bharu)'.

Respondent b: 'The land everywhere around Kampong Bharu is being developed. Just across the street is a high-rise. You go to Kampong Bharu, just opposite, there is a high-rise, 30storey, 40-storey developed by Malays and non-Malays, and yet Kampong Bharu prime land, a prime location, still not developed. It is baffling isn't it? ... they are really living below the subsistence and the standard level. You know, sanitary and health-wise and all that, because it is just left as a kampong'.

Respondent c: 'In my opinion, nowadays the development is a must. If you Google the Kampong Bharu, you will see that we area surrounded by all the high-rise buildings. We are looking like a slum area. So they have to develop. Kampong Bharu must be moving forward, to become part of the city centre ... so those who are the young people, who are intellectuals, can 
work in the city center over the day and night. They can live and work here. They can help develop KL and KL will become more competitive like Singapore, Bangkok, Jakarta and Manila'.

Drawing on the above and exploring the notion of greyness as the blurry space between what is officially whiten/accepted/enforced and blacken/delegitimized/criminalized by state power as the space of informality, this study demonstrates that the very construction of such iconic modern surroundings of Kampong Bharu has put pressure and diminished this historical inhabited area as the locus of informality in the heart of Kuala Lumpur. In other words, both the massive and continuous investment in the surrounding, as well as the lack of it, and abandonment throughout the years of Kampong Bharu reinforces its inequality, leaving the place as a 'grey' area, revealing the sharp role of state power in the production of informality through the urban development discourse and practices.

\subsection{MARKET FORCES}

Another influential theme that emerged throughout the exploration of issues of power within urban development practices in Kampong Bharu was the market forces. Making use of the provoking questions posed by Roy (2009: 77), which critically ask 'Who sets the urban upgrading agenda?' and 'Can the public interest of the city be left in the hands of private developers?'this study agrees with her and Watson (2006) demonstrating that both real state and private interests quite often drive the planning spatial choices in Kampong Bharu and surroundings. Although revealing different attitudes towards the market forces driving Kampong Bharu development, official documents, as well as interviewees, acknowledge the predominance of such hegemonic market rationality within the urban upgrading agenda of the area. Making use of examples such as infrastructure development and commodification of cultural aspects for attracting world-class tourists and business, as well as real estate developers, this research recognized the close relation between the issues of private power in reinforcing economic and ethnic divides.

As an example, for the government authority and development body representatives, some of Kampong Bharu Master Plan strategies, such as the increase of the plot ratio and the new possibilities of land use - presented at the previous section represent a major government step towards increasing the land value. For them, the major beneficiaries of such changes are the Kampong Bharu landowners, who can receive a higher amount of money from their piece of land. Nevertheless, local organizations as well as residents argue that these above-mentioned strategies are mostly benefiting the private companies and other groups of interest. For them, rather than focusing on what is best for the public, the government is interested in developing land which gets the best value out of the private investments in the region. In addition to that, those gatekeeper respondents shed light on the fact that the price and style of such high-rise constructions usually attract foreigners or other groups with money, reinforcing the aforementioned economic divides, keeping the city economic power on the hands of the same group. In addition to that, these respondents argue that such expression of the market poweris going to completely change the Malay character of the area, reinforcing the ethnic divide. In their words:

Respondent $\mathrm{d}$ : '... everything is going to turn into offices or condominiums. The population here will drop a bit, because people who usually buy condominium, do it as second home or as investment. So the daily business here and the small business here will not do so well. ... They (government) actually are doing all this not for the people, but is because if they do that, they attract the big guys and then they don't have to invest on the land'.

Respondent e:'This (plot-ratio) is for them to build high-rise condo or 
apartment whatever. But who's gonna buy if you sell it for more than 1 Million 1 condo? Our local here cannot afford. Yes. Locals cannot afford. Everybody, the Malays, we are gonna leave'.

All in all, casting a critical eye towards official phrases such as 'promotion of urban tourism as a catalyst for urban economic growth'and 'intensive mixed-use development as a way of attracting businesses, enhancing land value and attracting private investment'(PPKB, 2015), this study suggests the alignment of those urban practices with the already proven inadequate traditional planning practice. Embedded in such a mind-set, which has mostly originated in the Anglophone cities forged by the Industrial Revolution, the aboveexplored state power and market forces within the urban development practices have proven their share of responsibility in the very production of informality in Kampong Bharu, and consequently in Kuala Lumpur.

\section{CONCLUSION}

Addressing the UN-Habitat call for the exploration of a different planning approach to reduce inequality within growing cities - stated in the beginning of the paper - and framed by the global south urban studies' discussion about the issues of power in the production of informality, this paper has explored the informality in Kampong Bharu, Kuala Lumpur, through its urban development history. Casting a critical eye towards development practices discourses on 'fixing' informality issues, this study wishes to collaborate with the major discussion of an urban practice compromised with different ways of looking at informality. Hence, this paper critically addresses the parochialism of traditional urban practices that have been handling informality as something to be solved by planning rather than acknowledging the role of such state-led interventions in its production.

Rather than a police orientation, this paper follows an urban-studies approach focusing on exploring informality in the global south city of Kuala Lumpur, critically addressing the issues of power embedded in its development practices. Drawing on that, this study contributes to both further understand the history and background of planning in Kuala Lumpur, as well as encourage policy makers to undertake a critical analysis of the current development practices that challenge the deregulatory and exceptionalism logic embedded in the production of informality. Consistent with global south urbanists' claims of the importance of acknowledging and analysing the issues of power within informality, Kuala Lumpur and more specifically Kampong Bharu, have revealed, using Roy (2009: 86)'s words, that 'urban developmentalism remains damned by the very deregulatory logic that fuels it'. In acknowledging that, this paper wishes to invite planning practitioners in Kuala Lumpur and other global south cities to a paradigm shift that crityically addresses informality as somethingtaking place in the ever-shifting interface of state modernization efforts, urban administration, market regulation and their target population.

\section{REFERENCES}

Azuidah Y. (2011) Kampung Bharu, my neighbourhood. Jendela-DBKL. Kuala Lumpur: DBKL.

Bunnell T. (2002) Kampung Rules: Landscape and the Contested Government of Urban(e) Malayness. Urban Studies 39: 1685-1701.

Bunnell T. (2004) Re-viewing the Entrapment controversy: Megaprojection,(mis) representation and postcolonial performance. GeoJournal 59: 297-305.

Ju SR, Omar S and Ko YE. (2012) Modernization of the Vernacular Malay House In Kampong Bharu, Kuala Lumpur. Journal of Asian Architecture and Building Engineering 11: 95-102.

King R. (2008) Kuala Lumpur and Putrajaya: negotiating urban space in Malaysia: NUS Press.

Kuala Lumpur City Hall. (1984) Kuala Lumpur Structure Plan. Kuala Lumpur. 
Kuala Lumpur City Hall. (2006) Draft Kuala Lumpur City Plan 2020.

Kuala Lumpur City Hall. (2008) Draft Pelan Bandar Raya Kuala Lumpur 2020 Jilid

Nor RH. and Naziaty MY. (2011) Urban Landscape Changes in Kampung Baru, Kuala Lumpur, From 1969 to 2004 as Observed on Maps. Journal of Design and Built Environment 9 (December): 49-58.

Perbadanan Pembangunan Kampong Bharu. Akta 733. Kuala Lumpur: Percetakan Nasional Malaysia Berhad.

Parnell S and Oldfield S. (2014) The Routledge handbook on cities of the global south: Routledge.

PPKB. (2014) Pelan Induk Terperinci Pembangunan Kampong BharuPITPKB. Kuala Lumpur.

PPKB. (2015) http://www.pkb.gov.my.

Roy A. (2005) Urban Informality: Toward an Epistemology of Planning. Journal of the American Planning Association 71: 147-158.

Roy A. (2009) Why India Cannot Plan Its Cities: Informality, Insurgence and the Idiom of Urbanization. Planning Theory 8: 76-87.
4: Kampong Bharu. Kuala Lumpur: DBKL.

Miraftab F and Kudva N. (2014) Cities of the global South reader: Routledge.

Parlimen Malaysia. (2011) Akta 733

Sandercock L. (2003) Cosmopolis II: Mongrel Cities of the 21st Century, London \& New York: Continuum.

Selangor Go. (1951) Federation of Malaya Government Gazette. Kuala Lumpur.

Simone A. (2004) For the city yet to come: Changing African life in four cities: Duke University Press.

Teng YY. (2014) After more than a century, Kampung Baru remains very much a kampung. The Star Online.http://www.thestar.com.my.

UN-HABITAT. (2006) State of the World's Cities Report 2006/2007. United Nations Human Settlements Programme (UN-HABITAT).

Watson V. (2006) Deep difference: Diversity, planning and ethics. Planning Theory 5: 31-50.

Watson V. (2009) Seeing from the South: Refocusing urban planning on the globe's central urban issues. Urban Studies 46: 2259-2275.

Yiftachel O. (2009) Theoretical Notes On 'Gray Cities': the Coming of Urban Apartheid? Planning Theory 8: 88-100. 